\title{
Financial and Economic Risk: Empirical Evidence from the Spanish Construction Sector from 2003 to 2013
}

\author{
Juan Antonio Torrents Arévalo \\ Department of Management, Universitat Politècnica de Catalunya (BarcelonaTech) EPSEB, 08028 Barcelona, Spain
}

Received January 21, 2021; Revised March 4, 2021; Accepted March 23, 2021

\section{Cite This Paper in the following Citation Styles}

(a): [1] Juan Antonio Torrents Arévalo, "Financial and Economic Risk: Empirical Evidence from the Spanish Construction Sector from 2003 to 2013," Universal Journal of Accounting and Finance, Vol. 9, No. 2, pp. 145 - 159, 2021. DOI: 10.13189/ujaf.2021.090202.

(b): Juan Antonio Torrents Arévalo (2021). Financial and Economic Risk: Empirical Evidence from the Spanish Construction Sector from 2003 to 2013. Universal Journal of Accounting and Finance, 9(2), 145 - 159. DOI: 10.13189/ujaf.2021.090202.

Copyright $\mathrm{C} 2021$ by authors, all rights reserved. Authors agree that this article remains permanently open access under the terms of the Creative Commons Attribution License 4.0 International License

\begin{abstract}
Risk is an important factor in the business environment. Decisions have a risk associated with them, and the importance of this risk depends on the environment. Investing in the construction sector is not the same as investing in the banking sector. The possibility of loss requires one to know the maximum risk of sector each type and the implications for this on making the investment. In accordance with this, the objective of this report is to apply the economic and financial risks, which are more important from the business point of view in the construction sector from 2003 to 2013, which allows us to assess whether the risks in the years of growth in this sector are excessive. The data used to carry out this study come from the Bank for the Accounts of Companies Harmonized (BACH) and the methodology will be the formulas for economic and financial risk. The main results of this report are that the risk could advance the future problems of the construction sector while the report also enables an improvement in the risk management in different sectors. Furthermore, this concept ensures that the companies or the sectors could advance measures to optimize the management risk of these areas, especially the economic and financial areas. However, this methodology should be applied in other sectors during the same crisis period in Spain, since this would increase the performance of future studies.
\end{abstract}

Keywords Financial Risk, Economic Risk, Construction Risk, Statistical Size, Construction Risk

\section{Introduction}

In 2007, the annual Spanish Central Bank mentioned [1] that the first signs of slowdown in the real construction sector appeared in the middle of 2006 and gradually consolidated over 2007. The increase in interest rates and the lower expectations of home depreciation derived from the very maturation of the cycle in this market (really the increase prices of the real estate had been declining since 2004) and the prospective outlook for moderate growth in the net income of families led to a slowdown in the intense demand for housing. Therefore, the real activity of residential construction began to lose vigour. In May 2009, the monthly report by the European Central Bank [2] emphasized that in the case of Spain, the percentage of homes owned was $83 \%$ and the debt for home purchase was $58 \%$ of GDP.

As can be seen in Figure 1, the decrease in activity in the construction sector is shown and thus the impact this had on the Spanish economy. 


\section{Evolution: 2005-2013}

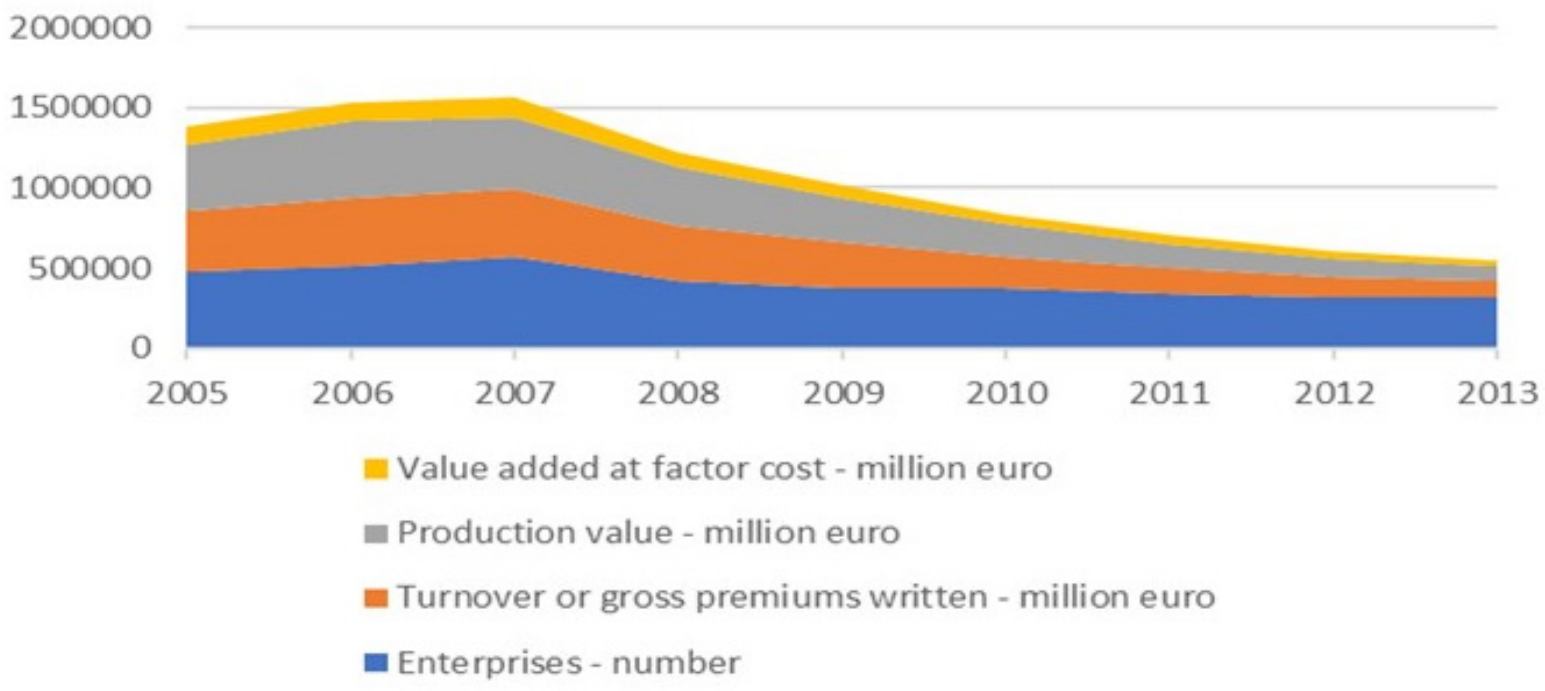

Source: Eurostat (2020).

Figure 1. Adaptation of a company to business risk

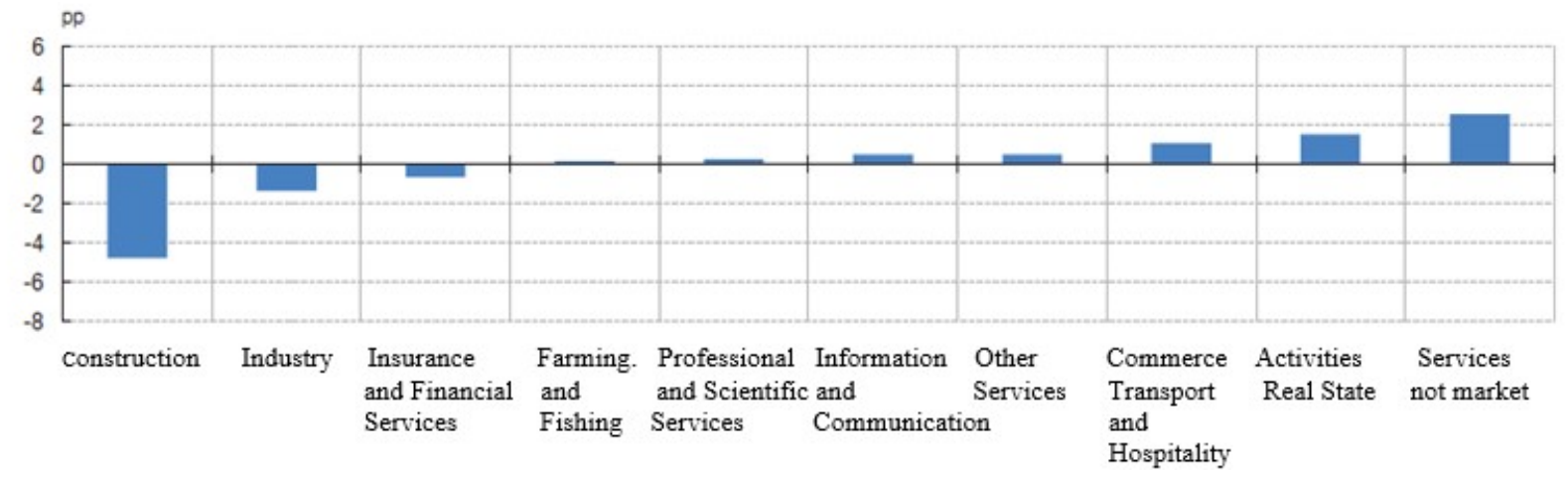

Source: Spanish Central Bank (2014).

Figure 2. Change in the structure of gross value added between 2013 and 2007.

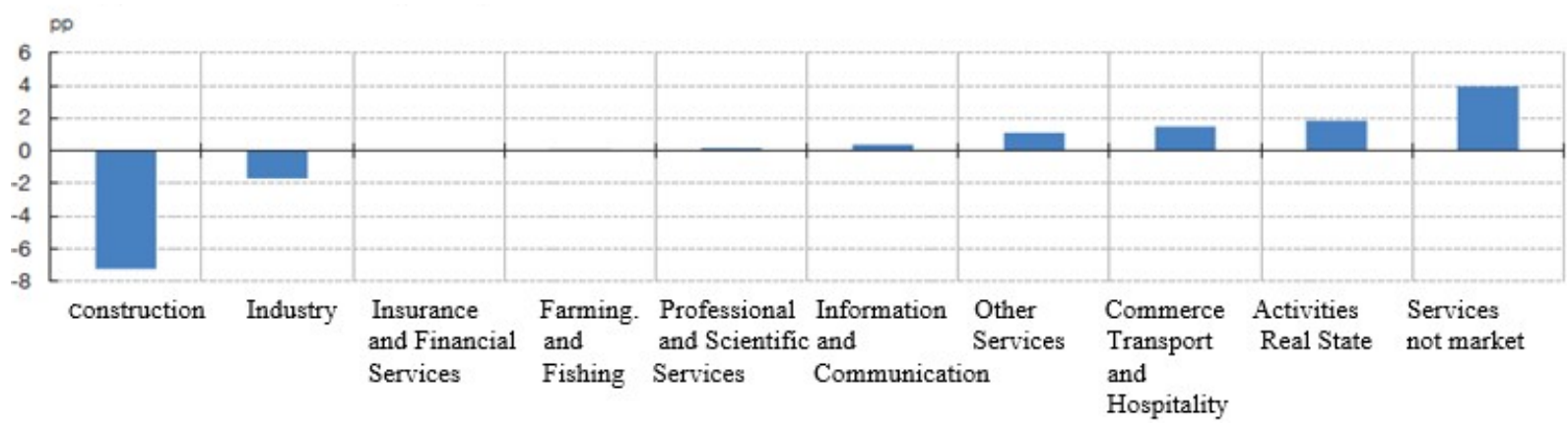

Source: Spanish Central Bank (2014).

Figure 3. Change in the structure of employment between 2013 and 2007.

I have analysed the different literature about the relationship between construction and financial risk. Following this approach, [3] mentioned that there is a strong dependence between the construction sector and the banking sector, which could affect the profitability and liquidity of companies in a possible economic and financial crisis. On the other hand, [4] study the relationship between bank profitability, related industry and determinants of macroeconomics determinants and the results show that, with the exception of liquidity, all specific determinants significantly affect bank profitability in the anticipated way. 
One of the most important impacts in the construction sector was the sectorial restructuring in the Spanish economy (Figures 2 and 3). The increase in the construction sector's GDP up to 2008 was reverted in the following year.

Consequence 2008 crisis. Employees in the construction sector changed employment since the Spanish economy needed to change the growth drive (Figures 4 and 5).

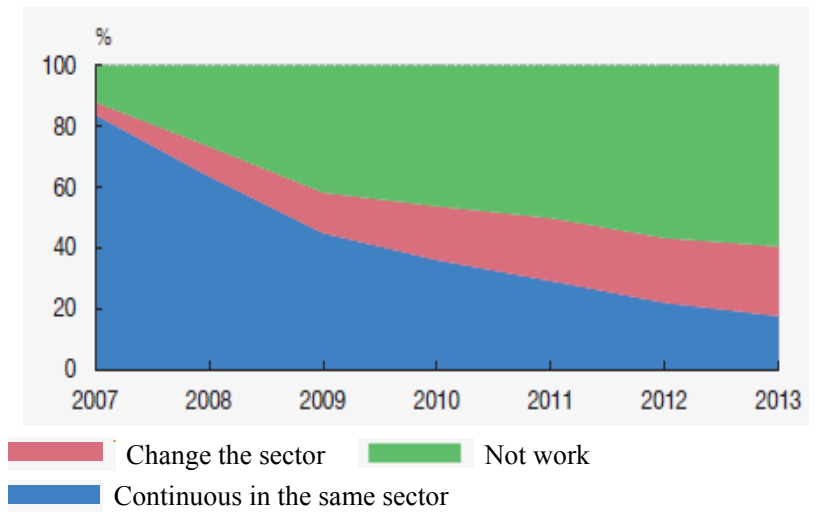

Source: Spanish Central Bank (2014).

Figure 4. Evolution of the labour situation between 2007 and 2013 in the construction sector in early 2007

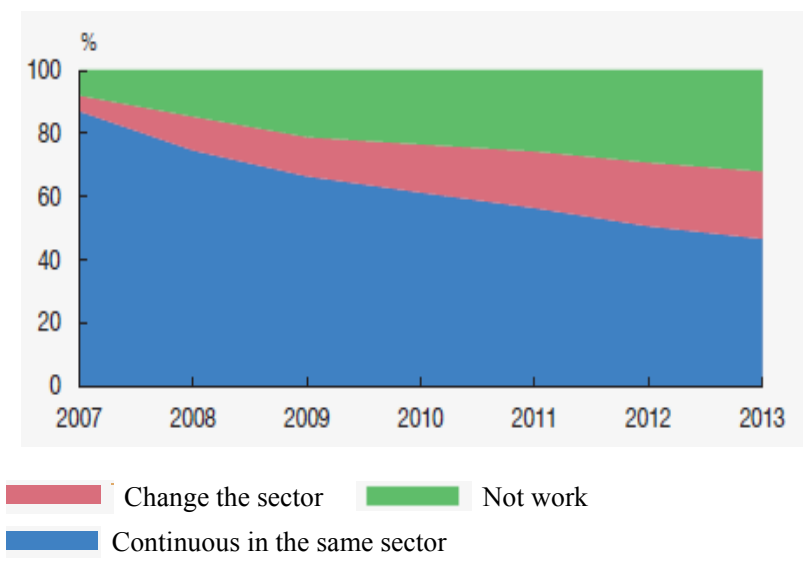

Source: Spanish Central Bank (2014).

Figure 5. Evolution of the labour situation between 2007 and 2013 in other sectors in early 2007

A consequence of the 2008 crisis in Spain, especially in the construction sector, was that the composition of the drivers were changed and the financial institutions had to change the structure of the loans and invest in different sectors that had more value added in order to avoid their investment being largely concentrated in the construction sector.

\section{Literature Review}

\subsection{Introduction}

There are many ways to classify risk $[5,6]$, including strategic, operational, and financial ways. Risk classification can also include the risk factor to determine which risks are systematic and specific to the company, which can be evaluated efficiently and numerically, and which are more qualitative and may depend on the perception of the environment, as in the current case of climate change and the importance that it plays today.

Regarding classifications, I can cite [7], which publishes a report that assesses risk over the next 10 years, including estimates of probability and possible impacts. The Allianz Risk Barometer [8] determines risks by geographical area. The Risk Management Initiative [9] determines the risks that will affect companies in the next 12 months.

In finance [10], risks emanate from the definitions of financial risk and risk models (namely from models where all potential future events are both controlled and accounted for) and uncertainty (namely from events that are not accounted for and, generally, events and consequences that are not considered in risk models namely, events that are neglected or unknown). In the first case, risk is defined in terms of potential financial losses (or risk exposure) and volatility. In the second case (uncertainty), risk arises from situations and states that are not accounted for by risk models. There are many financial risks, such as investors' risk of losses, bank risk, financial systems risk, and risks derived from sectors other than financial services.

Additionally, in [11] the authors demonstrate that] value at risk $(\mathrm{VaR})$ is one of the most important measures with which to evaluate the maximum loss of a company that could arise from market movements over a specific period. VaR is the distribution of the projected gains and losses over a holding period. If $\mathrm{X}$ is the variable that defines the changes in the amounts from the beginning of the period to the end, then $100(1-\alpha) \% \mathrm{VaR}$ of a long (L) position is defined as:

$$
\operatorname{VaR}(\mathrm{L})=\inf (\mathrm{x}: \mathrm{P}(\mathrm{X} \leq \mathrm{x}) \geq \alpha)
$$

The holder over an extended period has a loss when $\mathrm{X}$ $<0$ and $\alpha$ is small, but the holder over a brief period has a loss when $\mathrm{X}>0.100(1-\alpha) \% \mathrm{VaR}$ of a short $(\mathrm{S})$ position is defined by:

$$
\operatorname{VaR}(\mathrm{S})=\inf (\mathrm{x}: \mathrm{P}(\mathrm{X} \leq \mathrm{x}) \leq \alpha)
$$

When $\alpha$ is small, $\operatorname{VaR}(\mathrm{S})$ is positive and signifies that there is a loss for a short position.

\subsection{Economic Risk}

Economic risk appears [12] from circumstances to which the company is subjected, and it measures some of the risk factors affecting the company. Failures in productive process, changes in demand, and changes in the selling price or the cost factors are some of the circumstances that can cause the results to be not as expected. One of these circumstances may affect several 
companies simultaneously in the same way, which could lead us to call it a systematic risk, but it is certainly a specific risk, as each company can control the factors.

Another term that can be used for economic risk is business risk [13], which is the exposure to loss in value caused by fluctuations in volumes, margins and costs that stem from decreased demand, competitive pressure, operational efficiency, changes in regulation, etc. These fluctuations can occur because of internal, industry-wide, or wider market factors. In one of its simplest forms, business risk is regarded as the risk that, because of changes in margins and volumes, earnings will fall below the fixed cost base.

On the other hand, economic risk is a direct consequence of investment decisions, so that the structure of the assets of the company is responsible for the level and the variability of the operating profit.

This is a type of specific risk (not a systematic risk) since it only affects the investments in the company. In other words, the exposure varies according to the investment or the company in which the investment is made, and this will influence the selection policy for the assets of each investor.

It should be considered that this type of risk can produce big losses in the short term; for example, the appearance of new products or an economic crisis could lead to a significant decline in sales, causing a big loss to the company.

The following figure (Figure 6) summarizes how a company can adapt to business risk.

The basic calculation framework [13] is driven by the volatility in the Profit and loss (P\&L) and the multiple of capital that determines how much capital should eventually help to produce a given level of confidence. In addition, one can adjust the level of (un)certainty with respect to volatility. For the calculation of volatility, a P\&L time series can be used that needs to be cleansed of other risk events (markets, credit, etc.).

In this way, the benefit-cost ratio (BCR) method [14] tries to evaluate this risk for a project where the uncertainties are not explicitly considered. BCR is defined as the ratio of benefits to costs. The criteria examine whether the benefits of the project are high enough to justify the costs. Following this, we consider that the Earnings Before Interest and Taxes (EBIT) could be the way to evaluate part of the economic risk of the profit and loss account.

\section{Flexibility}

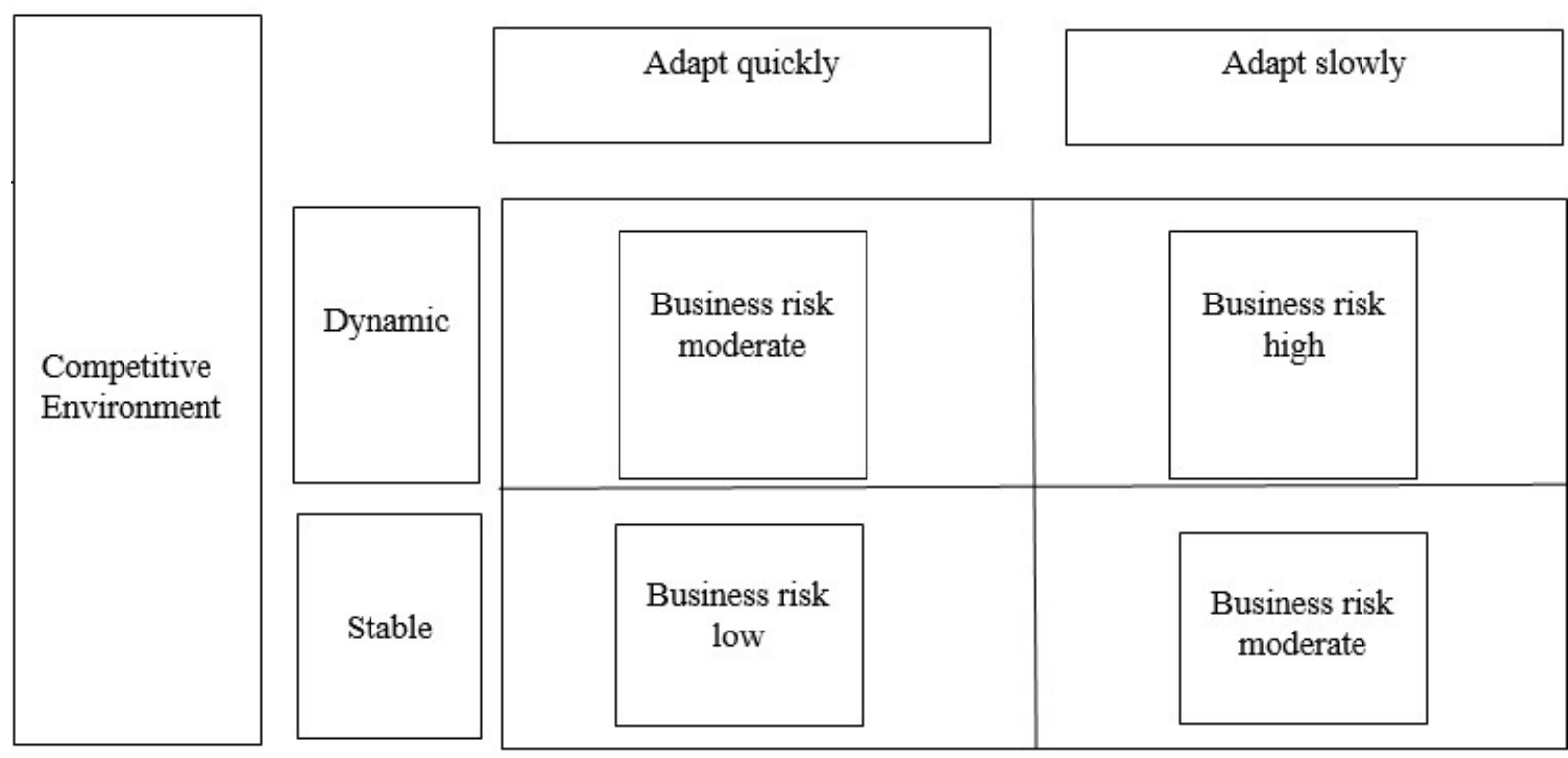

Source: Lelyveld (2006).

Figure 6. Adaptation of a company to business risk 
In more detail, the most important figure representing the magnitude of the economic activities of a company is earnings before tax and interest and, therefore, this measures the changes in the factors such as we have noted. For this reason, the usual way of measuring the economic risk is to measure the variability of profit in relative terms, or the economic profit of the return on investment (ROI). Variability measured by standard deviation follows the equation below:

$$
\sigma(R O I)=\frac{(1-t) \sigma(E B I T)}{E+L}
$$

Where:

$\sigma(\mathrm{ROI})$ is the standard deviation of economic profit, a measure of economic risk,

$t$ is the rate of corporate income tax,

$\sigma(\mathrm{EBIT})$ is the standard deviation of earnings before interest and tax,

$\mathrm{E}$ is the equity and

$\mathrm{L}$ is the liabilities.

\subsection{Financial Risk}

Financial risk is the major concern of a company today, because of the risk to the business or the market, since this factor can change the share price. In this sense Nueno and Pregel [15] when there is a financial risk the market quickly realizes this and adds it to the share price through the discount rate applied to future cash flows.

Measuring the risk of the financial position [16] is a complex process that relates to several features in the financial or insurance market. One hypothesis is to transfer the risk through the derivatives market (futures and options). The price of this product is part of the risk position, and the remaining part of the risk should be evaluated through a probability model and the preferences of the risk-taker. Therefore, measuring the risk relates to probabilistic modelling, with the price and preferences of the company and the shareholders.

To illustrate (Figure 7) the effect of changes in the financial price on the value of a company, we will introduce the concept of the risk profile of the company, specifically by measuring the variations suffered in the value of the company $(\mathrm{V})$ to the extent that there are some variations (P) (for example, in Madrid Interbank Offered Rate (MIBOR) or wheat).

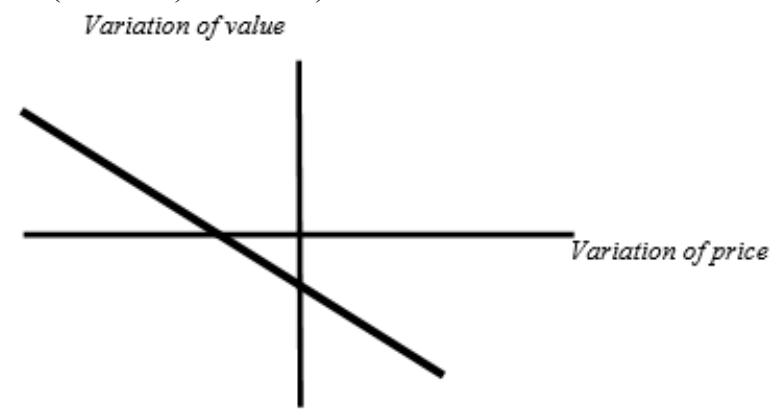

Source: Nueno and Pregel (1997).

Figure 7. Change in price against value.
A risk profile of this type means that future payments of the company depend on the price $\mathrm{P}$; if this fluctuates upwards, it will undermine the value of company, and vice versa.

On the other hand, financial risk refers to the variability of profits expected by the shareholders. Financial risk will probably be higher than economic risk because of financial leverage. Financial leverage occurs when a company finances part of its assets using debt, which implies a fixed financial cost, but with the hope for shareholders of an increase in performance.

Financial risk is a direct result of financial decisions because the composition of the capital structure of the company, or the level of financial leverage, directly affects the value. On the other hand [17] financial risk measures are often interpreted as the amount of capital to be held in reserve for risk portfolio or investment, and therefore it is important when constructing a risk method or index to measure it accurately. The goal of financial risk techniques $[18,19]$ is to maintain the appropriate level of cash and liquidity and to manage the uncertainty resulting from the outcomes, hence managing the total cost of risk.

From a practical point of view [12], risk can be defined to depend on derived performance variability in the proportion of borrowed funds used, and it appears in productive investment as a function of the profit split between external and equity funding. Also, risk appears in financial investment based on the proportion of equity used to support existing financial obligations.

The calculation of financial risk is obtained from the standard deviation of financial performance (RF), following this equation:

$$
R F=\frac{E(E B I T)(1-t)-I(1-t)}{E}
$$

where $E$ is the equity of the company. In other words, if average economic performance measures the profit from all providers' funds, financial performance measures the profit of an investor, the shareholder.

The standard deviation of financial performance from the equation above is:

$$
\sigma(\mathrm{RF})=\frac{\sigma(E B I T)(1-t))}{E}
$$

Substituting the equation, we found for economic risk, we get:

$$
\begin{aligned}
& \sigma(\mathrm{RF})=\frac{\sigma(R O I)(E+L))}{E} \\
& =\sigma(\mathrm{ROI}) * \frac{L}{(1+E)}
\end{aligned}
$$

Where:

$\sigma$ (ROI) is the standard deviation of an economic measure of economic risk.

$\mathrm{E}$ is the equity, and

$\mathrm{L}$ is the liabilities. 
Another element to be considered within risk is the relationship of risk and the indebtedness structure and, as a derivation thereof, the financial leverage [20-22]

$$
r=\frac{(E B I T) *(1-t)}{E+L}
$$

where:

$r$ is profitability

$\mathrm{t}$ is the tax rate; and

EBIT is earnings before interest and tax

If the EBIT is a random variable (E) and the indebtedness cost remains as a constant in relation to the indebtedness level, we can determine this in the following way (applying the average operator):

$$
E(r)=\frac{E((E B I T) *(1-t))}{E+L}
$$

The associated risk is determined as follows:

$$
\sigma(r)=\frac{\sigma((\text { EBIT }) *(1-t))}{E+L}
$$

If the equity $=$ total liabilities plus equity (there are no liabilities) and the economic structure remains stable:

$$
E\left(r^{*}\right)=\frac{E((E B I T) *(1-t))}{E}
$$

The associated risk will be determined as follows:

$$
\sigma\left(\mathrm{r}^{*}\right)=\frac{\sigma((\mathrm{EBIT}) *(1-\mathrm{t}))}{\mathrm{E}}
$$

Therefore $\sigma(\mathrm{r})>\sigma\left(\mathrm{r}^{*}\right)$.

Consequently, the shareholder's risk increases with the level of indebtedness.

Finally, the variability in profitability for shareholders depends on the economic structure (types of investment made by the company, evolution in price, costs, etc.) and on the way in which the investments are financed (the debt ratio).

\section{Data}

\subsection{Data}

The unit analysis is the firms of the construction sector and the variables (Variables I) defined in accordance with our analysis. The data used to carry out this study come from the Bank for the Accounts of Companies Harmonized [23]. The BACH is a database that provides comparable aggregated data (both economic and financial) based on the annual accounts of non-financial corporations of the following European countries: Austria, Belgium, the Czech Republic, France, Germany, Italy, Poland, Portugal and Spain.

Since it contains [23] data from annual balance sheets and income statements, the BACH database is an adequate data source for analysing the financial situation of non-financial corporations (NFCs). Currently, the data cover the period from 2000 onwards, and provide a sufficient level of detail by the business sector (17 NACE [Nomenclature of Economic Activities] sections and about 80 NACE divisions) and size (based on net turnover, allowing users to select small, medium, or large firms) for each country. Furthermore, two samples of annual data are available: a variable sample and a sliding sample. The variable sample (for each year) includes all corporations with known data for the selected year, while the sliding sample (containing two years) includes all corporations for which the data are available in two consecutive years. To sum up, the BACH database offers a variety of outputs for each combination of fiscal year, size of corporation, business sector and sample (variable or sliding).

The values of balance sheet ratios, income statement ratios and items from the notes expressed as weighted means should be determined once the absolute values for total assets and net turnover have been obtained.

The database used to conduct this research contained information for the construction sector in Spain from 2003 to 2013 for small, medium and large firms. We show in Table 1 the different items for the periods of coverage of this study. 
Table 1. Items Covered for the Construction Sector from 2003 to 2013

\begin{tabular}{|c|c|c|c|c|c|c|c|c|c|c|c|}
\hline Variable & 2003 & 2004 & 2005 & 2006 & 2007 & 2008 & 2009 & 2010 & 2011 & 2012 & 2013 \\
\hline $\mathrm{C} 1$ & 21.70 & 22.05 & 23.57 & 22.54 & 22.05 & 22.36 & 28.85 & 30.66 & 30.66 & 28.69 & 29.94 \\
\hline $\mathrm{C} 2$ & 31.73 & 32.33 & 34.67 & 34.59 & 34.35 & 40.58 & 49.61 & 51.16 & 55.49 & 54.24 & 55.63 \\
\hline AS & $100,062,579$ & $114,353,866$ & $147,316,103$ & $192,649,516$ & $222,123,109$ & $167,749,065$ & $192,117,717$ & $211,076,000$ & $194,205,697$ & $162,565,373$ & $132,855,231$ \\
\hline $\mathrm{TU}$ & $63,291,813$ & $73,240,867$ & $88,003,065$ & $105,207,049$ & $114,360,363$ & $99,686,033$ & $96,169,879$ & $84,366,568$ & $70,199,940$ & $55,439,661$ & $45,595,886$ \\
\hline $\mathrm{GV}$ & $18,863,834$ & $22,387,142$ & $26,453,939$ & $31,502,595$ & $32,909,496$ & $27,621,303$ & $28,026,113$ & $23,504,847$ & $20,279,835$ & $16,949,184$ & $13,995,905$ \\
\hline FI & 45,337 & 51,298 & 60,632 & 64,403 & 67,180 & 64,256 & 77,916 & 80,149 & 75,882 & 69,367 & 66,376 \\
\hline
\end{tabular}

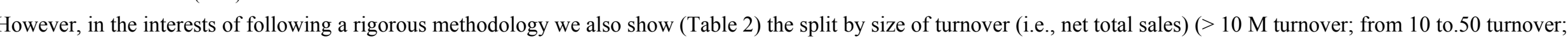
$<50 \mathrm{M}$ turnover).

Variables I: Definition

C1: coverage firms of total

C2: coverage employees of total

AS: total assets

TU: turnover

$\mathrm{GV}$ : gross value added

FI: firms

Table 2. Items Covered by Size of Company in the Construction Sector from 2003 to 2013

\begin{tabular}{|c|c|c|c|c|c|c|c|c|c|c|c|c|}
\hline Size & Variable & 2003 & 2004 & 2005 & 2006 & 2007 & 2008 & 2009 & 2010 & 2011 & 2012 & 2013 \\
\hline$<10 \mathrm{M}$ & $\mathrm{C} 1$ & $35,494,291$ & $41,089,647$ & $51,759,479$ & $57,144,838$ & $67,209,903$ & $51,178,755$ & $74,720,824$ & $78,472,734$ & $70,906,192$ & $61,746,072$ & $57,094,388$ \\
\hline$<10 \mathrm{M}$ & $\mathrm{C} 2$ & $28,916,079$ & $31,884,475$ & $38,476,499$ & $42,306,126$ & $44,341,220$ & $38,807,367$ & $38,346,711$ & $34,333,450$ & $28,684,308$ & $22,719,233$ & $20,009,224$ \\
\hline$<10 \mathrm{M}$ & AS & $10,431,883$ & $11,394,480$ & $13,685,401$ & $15,173,544$ & $16,022,968$ & $14,144,245$ & $14,397,033$ & $12,346,690$ & $10,403,362$ & $8,193,195$ & $7,519,959$ \\
\hline$<10 \mathrm{M}$ & $\mathrm{TU}$ & 44,776 & 50,563 & 59,774 & 63,354 & 66,079 & 63,460 & 77,050 & 79,374 & 75,194 & 68,827 & 65,968 \\
\hline$<10 \mathrm{M}$ & GV & 370,777 & 391,871 & 456,275 & 484,296 & 482,414 & 441,416 & 446,899 & 388,841 & 341,96 & 276,059 & 250,524 \\
\hline$>10 \mathrm{M}-50 \mathrm{M}$ & $\mathrm{C} 1$ & $12,789,280$ & $19,892,788$ & $23,054,086$ & $29,935,466$ & $34,741,676$ & $20,220,880$ & $20,346,669$ & $23,670,927$ & $25,938,992$ & $15,966,412$ & $11,255,271$ \\
\hline$>10 \mathrm{M}-50 \mathrm{M}$ & $\mathrm{C} 2$ & $7,554,584$ & $10,442,572$ & $11,771,697$ & $14,644,831$ & $14,254,711$ & $9,864,318$ & $10,522,206$ & $8,899,223$ & $7,942,929$ & $5,654,337$ & $4,650,470$ \\
\hline$>10 \mathrm{M}-50 \mathrm{M}$ & AS & $2,044,324$ & $2,836,951$ & $3,205,805$ & $3,894,108$ & $4,020,614$ & $2,684,339$ & $2,967,756$ & $2,505,828$ & $2,107,062$ & $1,574,227$ & $1,474,263$ \\
\hline$>10 \mathrm{M}-50 \mathrm{M}$ & $\mathrm{TU}$ & 468 & 630 & 717 & 874 & 904 & 612 & 671 & 580 & 524 & 379 & 300 \\
\hline$>10 \mathrm{M}-50 \mathrm{M}$ & $\mathrm{GV}$ & 31,111 & 40,463 & 46,321 & 55,379 & 50,612 & 43,540 & 51,702 & 47,782 & 43,244 & 35,100 & 30,981 \\
\hline$>50 \mathrm{M}$ & $\mathrm{C} 1$ & $51,779,007$ & $53,371,430$ & $72,502,536$ & $105,569,211$ & $120,171,530$ & $96,349,429$ & $97,050,224$ & $108,932,338$ & $97,360,517$ & $84,852,929$ & $64,505,607$ \\
\hline$>50 \mathrm{M}$ & $\mathrm{C} 2$ & $26,821,149$ & $30,913,819$ & $37,754,868$ & $48,256,091$ & $55,764,431$ & $51,014,347$ & $47,300,961$ & $41,133,894$ & $33,572,702$ & $27,066,090$ & $20,936,190$ \\
\hline$>50 \mathrm{M}$ & AS & $6,387,743$ & $8,155,947$ & $9,565,523$ & $12,434,941$ & $12,865,912$ & $10,792,717$ & $10,661,323$ & $8,652,328$ & $7,769,410$ & $7,181,761$ & $5,001,683$ \\
\hline$>50 \mathrm{M}$ & $\mathrm{TU}$ & 93 & 105 & 141 & 175 & 197 & 184 & 195 & 195 & 164 & 161 & 108 \\
\hline$>50 \mathrm{M}$ & $\mathrm{GV}$ & 83,659 & 97,380 & 110,733 & 120,310 & 144,405 & 134,970 & 139,521 & 125,048 & 108,928 & 98,656 & 80,038 \\
\hline
\end{tabular}

Source: BACH database (2016). 
The $\mathrm{BACH}$ project also has details by percentage of financial statement entries (Balance Sheet and Profit and Loss). Following these criteria, the variables that are used are as follows:

Table 3. Database Concepts

\begin{tabular}{|c|c|c|}
\hline Code & Definition & Contents \\
\hline $\mathrm{I} 1$ & Net turnover & Includes sales of goods and services, net of returns, deductions, and rebates. Sales are net of VAT and excise taxes. \\
\hline $\mathrm{I} 2$ & Variation in stocks of finished goods and work in progress & Includes change in inventories of production recognized in the income statement. \\
\hline I3 & Capitalized production & Includes costs capitalized by the entity recognized as income in the period. \\
\hline I4 & Other income & Includes other income not identified in previous items (I1, I2 and I3). \\
\hline I5 & Cost of goods sold materials and consumables & Includes cost of materials and consumables used and the cost of goods sold in the period. \\
\hline I6 & External supplies and services & Includes expenses for external supplies and services in the period. \\
\hline I7 & Staff costs & Includes expenses for staff recognized in the period. \\
\hline I8 & Other expenses & Includes other expenses not identified in previous items (I5, I6 and I7). \\
\hline I9 & $\begin{array}{l}\text { Depreciation and amortization of intangible and tangible } \\
\text { fixed assets }\end{array}$ & Includes depreciation and amortization of assets. \\
\hline $\mathrm{E}$ & Equity & Total equity. \\
\hline L12 & Bonds and similar obligations (non-current) & Includes bonds and securities issued by the entity. \\
\hline L22 & Amounts owed to credit institutions (non-current) & Includes debt of the entity to finance companies and credit institutions (including leasing). \\
\hline L321 & Other financial creditors (non-current) & Includes the remaining funding of the entity. \\
\hline A & Assets & Total assets. \\
\hline
\end{tabular}

Table 4. Figures for Analysis of Company Size $<10 \mathrm{M}(2003-2013)$

\begin{tabular}{|c|c|c|c|c|c|c|c|c|c|c|c|}
\hline Variables & 2003 & 2004 & 2005 & 2006 & 2007 & 2008 & 2009 & 2010 & 2011 & 2012 & 2013 \\
\hline Employees & 370,777 & 391,870 & 456,275 & 484,296 & 482,414 & 441,416 & 446,899 & 388,841 & 341,960 & 276,059 & 250,524 \\
\hline Assets & $35,494,291$ & $41,089,647$ & $51,759,479$ & $57,144,838$ & $67,209,903$ & $51,178,755$ & $74,720,824$ & $78,472,734$ & $70,906,192$ & $61,746,072$ & $57,094,388$ \\
\hline Net Turnover & $28,916,079$ & $31,884,475$ & $38,476,499$ & $42,306,126$ & $44,341,220$ & $38,807,367$ & $38,346,711$ & $34,333,450$ & $28,684,308$ & $22,719,233$ & $20,009,224$ \\
\hline Equity & $11,695,369$ & $13,838,993$ & $16,754,543$ & $17,846,333$ & $20,861,954$ & $17,231,887$ & $26,421,283$ & $30,055,057$ & $29,773,510$ & $28,100,637$ & $27,496,657$ \\
\hline EBIT & $2,145,573$ & $2,416,843$ & $2,901,128$ & $3,316,800$ & $3,409,840$ & $1,664,836$ & $1,303,788$ & 645,469 & $-68,842$ & $-322,613$ & $-64,030$ \\
\hline Tax rate & $35 \%$ & $35 \%$ & $35 \%$ & $35 \%$ & $35 \%$ & $35 \%$ & $35 \%$ & $35 \%$ & $35 \%$ & $35 \%$ & $35 \%$ \\
\hline EBIT net & $1,394,622$ & $1,570,948$ & $1,885,733$ & $2,155,920$ & $2,216,396$ & $1,082,143$ & 847,462 & 419,555 & $-44,748$ & $-209,699$ & $-41,619$ \\
\hline $\mathrm{L} 12$ & 0 & 0 & 0 & 0 & 0 & 0 & 0 & 0 & 0 & 0 & 0 \\
\hline $\mathrm{L} 22$ & $5,966,590$ & $7,034,590$ & $9,948,172$ & $12,051,846$ & $15,787,606$ & $10,977,943$ & $18,956.673$ & $18,731,442$ & $15,081,747$ & $11,552,690$ & $9,323,514$ \\
\hline $\mathrm{L} 32$ & $8,767,092$ & $1,010,805$ & $1,635,805$ & $1,114,324$ & $1,774,341$ & $2,379,812$ & $3,848,122$ & $4,637,739$ & $4,339,459$ & $4,087,590$ & $9,323,514$ \\
\hline Economic Risk & & & & & & 0.00866 & & & & & 0.00573 \\
\hline $2008 \%$ & & & & & & 0.86697 & & & & & 0.57343 \\
\hline Financial Risk & & & & & & 0.01539 & & & & & 0.00853 \\
\hline $2008 \%$ & & & & & & 1.53903 & & & & & 0.85265 \\
\hline Profitability & 0.03929 & 0.03823 & 0.03643 & 0.00377 & 0.03927 & 0.02114 & 0.01134 & 0.00534 & -0.00063 & -0.00339 & -0.00072 \\
\hline$\%$ & 3.92915 & 3.82322 & 3.64326 & 3.77227 & 3.29772 & 2.11444 & 1.13417 & 0.53465 & 0.06311 & -0.33961 & -0.07290 \\
\hline
\end{tabular}

Source: Authors (L12, L22 and L32 calculated from \% of total assets, EBIT calculated from \% total net turnover) 


\section{Empirical Statistics}

\subsection{Construction Sector, With Company Size $<10 \mathrm{M}$}

\subsubsection{Figures}

This section shows empirical findings for companies with size $<10 \mathrm{M}$. We analyse the random variables for economic risk, financial risk and profitability up to 2008 (period 2003-2008) and up to 2013 (period 2009-2013).

Table 4 shows the figures obtained from the $\mathrm{BACH}$ database for the construction sector for companies of size less than $10 \mathrm{M}$ euros.

\subsubsection{Statistical results}

Additionally, we have calculated the statistical parameters to determine the correlation of profitability:

Profitability $=\beta 1$ EBIT $+\beta 2$ Assets $+\beta 3$ Debt $+\beta 4$ Net Turnover $+\beta 5$ Equity $(\beta \mathrm{N}$ : Constant)

This model tries to determine whether profitability is correlated with the other variables.

Table 5. Correlation Model

\begin{tabular}{|c|c|c|c|c|c|}
\hline $\mathrm{R}$ & $\mathrm{R} 2$ & $\begin{array}{c}\text { Correct } \\
\mathrm{R} 2\end{array}$ & $\begin{array}{c}\text { Error tip } \\
\text { of the } \\
\text { estimation }\end{array}$ & $\begin{array}{c}\text { Statistical } \\
\text { changes } \\
\mathrm{R} 2 \\
\text { Changes }\end{array}$ & $\begin{array}{c}\text { Statistical } \\
\text { changes } \\
\text { in F }\end{array}$ \\
\hline 0.876 & 0.767 & 0.534 & 0.122448 & 0.767 & 3.296 \\
\hline
\end{tabular}

Source: Authors.
Table 6. Descriptive Statistics for Selected Variables

\begin{tabular}{|cccc|}
\hline Variable & Mean & Standard deviation & $\mathrm{N}$ \\
\hline Profitability & 0.017279 & 0.0179469 & 11 \\
Assets & $58,801,556.64$ & $13,552,005.117$ & 11 \\
Net Turnover & $33,529,517.45$ & $7,856,388.303$ & 11 \\
Equity & $21,825,111.18$ & $6,724,530.284$ & 11 \\
EBIT & $1,577,162.91$ & $1,383,059.925$ & 11 \\
EBIT net & $1,025,155.73$ & $898,989.007$ & 11 \\
Debt & $15,733,911.09$ & $4,693,791.636$ & 11 \\
\hline
\end{tabular}

Source: Authors.

\subsubsection{Analysis}

The figures show that economic and financial risk were higher in 2008 than 2013. Profitability followed the same direction: from 2003 to 2008 the percentage was higher than from 2009 to 2013. It therefore seems that having more risk may indicate greater profitability, although it may be that the risk is simply a warning that the company could have problems in the future. In addition, we can see that the reduction in risk is derived from the reduction in profitability, implying the need for balance to recover an adequate structure for financial leverage.

Examining the results in Table 8 for the statistical parameters shows that indebtedness leads to worse profitability, which implies excessive financial leverage (negative), which implies that the company is growing in an uncontrolled manner. This can be verified by looking at the total assets, whose value also damages this controlled growth. The result confirms that the leverage risk was excessive in 2008 and could have been an indicator that a certain prudence should have been used. On the other hand, $\mathrm{R}$ allows us to determine an adequate value for the correlation of profitability, assets, EBIT, debt, and equity.

Table 7. Pearson Correlation

\begin{tabular}{|ccccccccc|}
\hline & Profitability & Net turnover & Assets & EBIT net & Equity & Debt & EBIT \\
\hline Profitability & 1.000 & .435 & -.583 & .740 & -.804 & -.418 & .740 \\
Assets & -.583 & .153 & 1.000 & -.379 & .862 & .845 & -.379 \\
Net Turnover & .435 & 1.000 & .153 & .798 & -.357 & .099 & .798 \\
Equity & -.804 & -.357 & .862 & -.768 & 1.000 & .705 & -.768 \\
EBIT & .740 & .798 & -.379 & 1.000 & -.768 & -.384 & 1.000 \\
EBIT net & .740 & .798 & -.379 & 1.000 & -.768 & -.384 & 1.000 \\
Debt & -.418 & .099 & .845 & -.384 & .705 & 1.000 & -.384 \\
\hline
\end{tabular}

Source: Authors. 


\subsection{Construction Sector, with Company Size $10 \mathrm{M}$ to $50 \mathrm{M}$}

4.2.1. Figures

The table below shows the empirical findings for companies with size from $10 \mathrm{M}$ to $50 \mathrm{M}$.

Table 8. Figures for Analysis for Companies with Size 10 M-50 M (2003-2013)

\begin{tabular}{|c|c|c|c|c|c|c|c|c|c|c|c|}
\hline Variables & 2003 & 2004 & 2005 & 2006 & 2007 & 2008 & 2009 & 2010 & 2011 & 2012 & 2013 \\
\hline Employees & 31,111 & 40,463 & 46,321 & 55,379 & 50,612 & 43,540 & 51,702 & 47,782 & 43,244 & 35,100 & 30,981 \\
\hline Assets & $12,789,280$ & $19,892,788$ & $23,054,086$ & $29,935,466$ & $34,741,676$ & $20,220,880$ & $20,346,669$ & $23,670,927$ & $25,938,992$ & $15,966,412$ & $11,255,271$ \\
\hline Net Turnover & $7,554,584$ & $10,442,572$ & $11,771,697$ & $14,644,831$ & $14,254,711$ & $9,864,318$ & $10,522,206$ & $8,899,223$ & $7,942,929$ & $5,654,337$ & $4,650,470$ \\
\hline Equity & $3,944,214$ & $5,408,849$ & $6,409,036$ & $8,432,821$ & $9,758,937$ & $6,175,457$ & $6,671,673$ & $6,552,113$ & $5,613,198$ & $4,053,872$ & $3,238,141$ \\
\hline EBIT & $1,005,515$ & $1,499,553$ & $1,611,545$ & $2,064,921$ & $2,069,784$ & 766,458 & 935,424 & 172,645 & $-356,638$ & $-821,575$ & $-282,749$ \\
\hline Tax rate & $35 \%$ & $35 \%$ & $35 \%$ & $35 \%$ & $35 \%$ & $35 \%$ & $35 \%$ & $35 \%$ & $35 \%$ & $35 \%$ & $35 \%$ \\
\hline EBIT net & 653,585 & 974,710 & $1,047,504$ & $1,342,199$ & $1,345,360$ & 498,197 & 608,026 & 112,219 & $-231,814$ & $-534,024$ & $-183,787$ \\
\hline $\mathrm{L} 12$ & 0 & 0 & 0 & 20,955 & 0 & 36,398 & 22,381 & 21,304 & 5,188 & 0 & 1,126 \\
\hline L22 & $2,378,806$ & $4,105,871$ & $5,447,681$ & $6,777,390$ & $9,022,413$ & $3,977,447$ & $3,646,123$ & $4,265,501$ & $4,497,821$ & $3,356,140$ & $1,669,157$ \\
\hline L32 & 425,883 & 843,454 & 749,258 & $1,116,593$ & $1,278,494$ & 746,150 & 921,704 & $2,305,548$ & $3,229,405$ & $1,486,473$ & $1,206,565$ \\
\hline Economic Risk & & & & & & 0.06107 & & & & & 0.04285 \\
\hline $2008 \%$ & & & & & & 6.10726 & & & & & 4.28593 \\
\hline Financial Risk & & & & & & 0.10815 & & & & & 0.08094 \\
\hline $2008 \%$ & & & & & & 10.8146 & & & & & 8.09366 \\
\hline Profitability & 0.05110 & 0.04900 & 0.04544 & 0.04484 & 0.03872 & 0.02464 & 0.02988 & 0.00474 & -0.00894 & -0.03345 & -0.01633 \\
\hline$\%$ & 5.11041 & 4.89981 & 4.54368 & 4.48364 & 3.87247 & 2.46378 & 2.98833 & 0.47408 & -0.89369 & -3.34467 & -1.63289 \\
\hline
\end{tabular}

Source: Authors (L12, L22 and L32 calculated from \% of total assets, EBIT calculated from $\%$ total net turnover). 


\subsubsection{Statistical results}

Additionally, we have calculated the statistical parameters to determine the correlation, as in section 4.1.2:

Table 9. Correlation Model

\begin{tabular}{|c|c|c|c|c|c|}
\hline $\mathrm{R}$ & $\mathrm{R} 2$ & $\begin{array}{c}\text { Correct } \\
\mathrm{R} 2\end{array}$ & $\begin{array}{c}\text { Error of } \\
\text { the } \\
\text { estimation }\end{array}$ & $\begin{array}{c}\text { Statistical } \\
\text { changes } \\
\mathrm{R} 2 \\
\text { Changes }\end{array}$ & $\begin{array}{c}\text { Statistical } \\
\text { changes } \\
\text { Changes } \\
\text { in F }\end{array}$ \\
\hline 0.975 & 0.951 & 0.903 & 0.091989 & 0.951 & 19.589 \\
\hline
\end{tabular}

Source: Authors.

Table 10. Descriptive Statistics for Selected Variables

\begin{tabular}{|cccc|}
\hline Variable & Mean & Standard deviation & $\mathrm{N}$ \\
\hline Profitability & .020400 & .0295150 & 11 \\
Assets & $21,619,313.36$ & $7,001,259.865$ & 11 \\
Net Turnover & $9,654,716.18$ & $3,176,744.375$ & 11 \\
Equity & $6,023,482.82$ & $1,927,092.089$ & 11 \\
EBIT & $787,716.64$ & $997,679.022$ & 11 \\
EBIT net & $512,015.91$ & $648,491.484$ & 11 \\
Debt & $5,778,293.55$ & $2,257,159.762$ & 11 \\
\hline
\end{tabular}

Source: Authors.

\subsubsection{Analysis}

In this section we analyse companies with size from 10 $\mathrm{M}$ to $50 \mathrm{M}$ and follow the same structure as for companies with a size less than $10 \mathrm{M}$. The economic risk and financial risk were higher in 2008 than in 2013, and the same is true for profitability. As for the findings in the correlation model, the $\mathrm{R}$ shows a good result for determining the key points for profitability. However, in this case the correlation shows a positive sign for all the variables, which is different from companies with a size less than $10 \mathrm{M}$, and therefore the increase in profitability is a consequence not only of Net Turnover and EBIT but also of Debt, Assets and Equity, although the values here are low. This could indicate that profitability grows if the correlation is positive, but also, as can be seen from the beginning of the crisis in 2009, if this growth is not adequately balanced in the structure, any drastic change does not create a reaction in the short term, and strategies that last several years are needed to correct the excesses of indebtedness.

An interesting result emerges when we evaluate the impact of Net Turnover on profitability, since the correlation is higher than it is for companies of a size less than $10 \mathrm{M}$. This means that the profit is derived from the turnover, not from the optimization of the profit and loss statements.

Table 11. Pearson Correlation

\begin{tabular}{|ccccccccc|}
\hline & Profitability & Net Turnover & Assets & EBIT net & Equity & Debt & EBIT \\
\hline Profitability & 1.000 & .729 & .326 & .924 & .477 & .162 & .924 \\
Assets & .326 & .837 & 1.000 & .563 & .944 & .973 & .563 \\
Net Turnover & .729 & 1.000 & .837 & .898 & .925 & .711 & .898 \\
Equity & .477 & .925 & .944 & .712 & 1.000 & .863 & .712 \\
EBIT & .924 & .898 & .563 & 1.000 & .712 & .415 & 1.000 \\
EBIT net & .924 & .898 & .563 & 1.000 & .712 & .415 & 1.000 \\
Debt & .162 & .711 & .973 & .415 & .863 & 1.000 & .415 \\
\hline
\end{tabular}

Source: Authors. 


\subsection{Construction Sector for Companies with Size $>50 \mathrm{M}$}

4.3.1. Figures

The table below shows the empirical findings for companies with size greater than $50 \mathrm{M}$.

Table 12. Figures for Analysis for Companies with Size $>50$ M (2003-2013)

\begin{tabular}{|c|c|c|c|c|c|c|c|c|c|c|c|}
\hline Variables & 2003 & 2004 & 2005 & 2006 & 2007 & 2008 & 2009 & 2010 & 2011 & 2012 & 2013 \\
\hline Employees & 83,659 & 97,380 & 110,733 & 120,310 & 144,405 & 134,970 & 139,521 & 125,048 & 108,928 & 98,656 & 80,038 \\
\hline Assets & $51,779,007$ & $53,371,430$ & $72,502,536$ & $105,569,211$ & $120,171,530$ & $96,349,429$ & $97,050,224$ & $108,932,338$ & $97,360,517$ & $84,852,929$ & $64,505,607$ \\
\hline Net Turnover & $26,821,149$ & $30,913,819$ & $37,754,868$ & $48,256,091$ & $55,764,431$ & $51,014,347$ & $47,300,961$ & $41,133,894$ & $33,572,702$ & $27,066,090$ & $20,936,190$ \\
\hline Equity & $18,909,693$ & $12,136,663$ & $15,994,059$ & $22,422,900$ & $22,556,196$ & $13,835,778$ & $13,926,707$ & $15,370,353$ & $10,670,713$ & $5,863,337$ & $1,870,663$ \\
\hline EBIT & $2,888,638$ & $3,864,227$ & $5,081,805$ & $7,479,694$ & $6,217,734$ & $-3,040,455$ & $1,740,675$ & 115,175 & $-275,296$ & $-6,317,225$ & $-2,711,237$ \\
\hline Tax rate & $35 \%$ & $35 \%$ & $35 \%$ & $35 \%$ & $35 \%$ & $35 \%$ & $35 \%$ & $35 \%$ & $35 \%$ & $35 \%$ & $35 \%$ \\
\hline EBIT net & $1,877,615$ & $2,511,748$ & $3,303,173$ & $4,861,801$ & $4,041,527$ & $-1,976,296$ & $1,131,439$ & 74,864 & $-178,943$ & $-4,106,197$ & $-1,762,304$ \\
\hline L12 & 176,049 & 122,754 & 79,753 & 126,683 & 805,149 & 616,636 & 601,711 & $1,111,110$ & $1,109,910$ & $1,238,853$ & 51,604 \\
\hline L22 & $5,623,200$ & $7,760,206$ & $13,753,731$ & $20,554,325$ & $27,302,972$ & $13,055,348$ & $12,383,609$ & $18,169,914$ & $19,647,352$ & $14,781,380$ & $10,869,195$ \\
\hline L32 & $1,025,224$ & $1,328,949$ & $1,848,815$ & $3,082,621$ & $2,860,082$ & $3,507,119$ & $3,027,967$ & $5,130,713$ & $9,103,208$ & $6,660,955$ & $5,224,954$ \\
\hline Economic & & & & & & 0.06877 & & & & & 0.07972 \\
\hline Risk $2008 \%$ & & & & & & 6.87799 & & & & & 7.97202 \\
\hline Financial & & & & & & 0.15418 & & & & & 0.76779 \\
\hline Risk $2008 \%$ & & & & & & 15.4178 & & & & & 76.7788 \\
\hline Profitability & 0.03626 & 0.04706 & 0.04556 & 0.04605 & 0.03363 & -0.02051 & 0.01166 & 0.00069 & -0.00184 & -0.04839 & -0.02372 \\
\hline$\%$ & 3.62621 & 4.70617 & 4.5559 & 4.60532 & 3.36313 & -2.50511 & 1,16583 & 0,06872 & $-0,18379$ & $-4,83919$ & $-2,73202$ \\
\hline
\end{tabular}

4.3.2. Statistical results

Additionally, the statistical parameters are shown, following the correlation in section 4.1.2:

Table 13. Correlation Model

\begin{tabular}{|c|c|c|c|c|}
\hline $\mathrm{R}$ & $\mathrm{R} 2$ & Correct R2 & Error of the estimation & $\begin{array}{c}\text { Statistical changes } \\
\mathrm{R} 2 \mathrm{Changes}\end{array}$ \\
\hline 0.990 & 0.981 & 0.961 & 0.0064854 & 0.981 \\
\hline
\end{tabular}

Source: Authors. 
Table 14. Descriptive Statistics for Selected Variables

\begin{tabular}{|cccc|}
\hline Variable & Mean & Standard deviation & N \\
\hline Profitability & .011495 & .0329664 & 11 \\
Assets & $86,585,887.09$ & $23,048,317.431$ & 11 \\
Net Turnover & $38,230,412.91$ & $11,364,182.957$ & 11 \\
Equity & $13,959,732.91$ & $6,340,423.809$ & 11 \\
EBIT & $1,367,612.27$ & $4,274,982.698$ & 11 \\
EBIT net & $888,947.91$ & $2,778,738.917$ & 11 \\
Debt & $19,340,186.45$ & $7,751,677.688$ & 11 \\
\hline
\end{tabular}

Source: Authors.

Table 15. Pearson Correlation

\begin{tabular}{|ccccccccc|}
\hline & Profitability & Net Turnover & Assets & EBIT net & Equity & Debt & EBIT \\
\hline Profitability & 1.000 & .287 & -.123 & .959 & .743 & -.234 & .959 \\
Assets & -.123 & .787 & 1.000 & .111 & .400 & .858 & .111 \\
Net Turnover & .287 & 1.000 & .787 & .445 & .706 & .446 & .445 \\
Equity & .743 & .706 & .400 & .810 & 1.000 & .144 & .810 \\
EBIT & .959 & .445 & .111 & 1.000 & .810 & -.007 & 1.000 \\
EBIT net & .959 & .445 & .111 & 1.000 & .810 & -.007 & 1.000 \\
Debt & -.234 & .446 & .858 & -.007 & .144 & 1.000 & -.007 \\
\hline
\end{tabular}

Source: Authors.

\subsubsection{Analysis}

It can be seen in this section that the economic risk is stable during the whole period of study, since from 2003 to 2008 the figure was $6.877 \%$ and from 2009 to 2013 it was $7.977 \%$. However, the financial risk showed a different behaviour, since it went from $15.41 \%$ in 2008 to $76.78 \%$ in 2013 , so that in this case the growth was a consequence of excessive financial leverage. On the other hand, the profitability has a negative correlation with the assets and debt; for this reason, it is necessary to achieve optimal debt as the company grows.

With regard to the model correlation, the $\mathrm{R}$ is as good as with the companies of size $10 \mathrm{M}$ to $50 \mathrm{M}$, but the key finding is that the growth of profitability is a consequence of the EBIT and not of the Net Turnover. The companies therefore decided to establish a growth strategy focused not only on Net Turnover but also on the optimization of the profit and loss statement.

Finally, the standard deviation is too big; this may imply unequal growth from 2003 to 2013 because the sector is closely related to public administrations in Spain and other countries and we should point out that large companies run with more risks due to the volume of investments not only in Spain but also in other countries, such as in South America, large companies run with more risks due to the volume of investments they make, and therefore the 2008 crisis had a greater impact and so the standard deviation is higher than other companies with lower dimensions.

\section{Concluding Remarks}

This paper adds to the literature dealing with the determinants of economic and financial risk for companies, especially in the construction sector. The main conclusion emerging from my empirical results, which show the application of the concept of risk in business, allows potential problems for companies in the future to be avoided. The conclusions of the study (Figure 8) are that small and medium-sized construction companies showed more prudent behaviour in terms of economic and, especially, financial risk, but the large companies did not.

It can be seen from the proportions in terms of employment that the small companies played a key role, but in terms of value added, the large companies had a significant impact on the economy. When the economic crisis seriously affected the construction sector, the risk of the important companies therefore produced a proportional decrease in results and employment.

Furthermore, we recommend that a mechanism be introduced to control financial risk, so that companies do not reach excessive indebtedness in correlation with economic growth.

In general terms, the growth in the construction sector in Spain was favoured by an extraordinary economic growth and an increase in employment, with a high rate of unemployment being absorbed and immigration with great employment prospects being promoted, but this also contributed to perpetuating the main structural weakness of the Spanish economy, with a majority of low-skilled labour, to the detriment of other more efficient sectors, and to widening the gap in industrial productivity that already existed between the Spanish economy and the economies of the rest of Europe. 


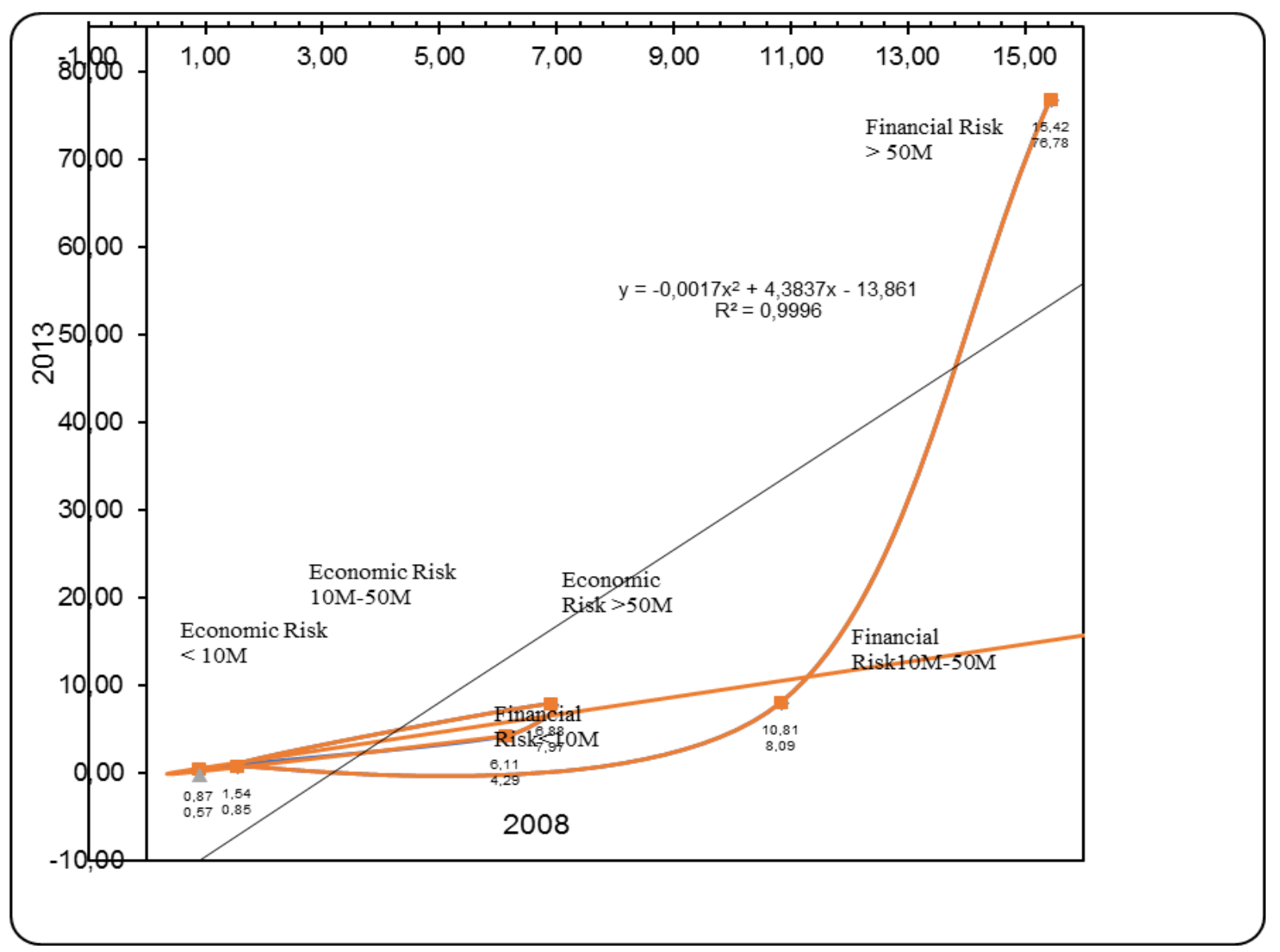

Source: Authors.

Figure 8. Correlation of economic and financial risk 2008 vs 2013.

\section{REFERENCES}

[1] Banco de España. Informe Anual 2007. $1^{\text {st }}$ ed. Madrid 2008 pp. $1-45$

[2] European Central Bank (2009). May Monthly Report. $1^{\text {st }}$ ed. Frankfurt pp. 56-61

[3] Kahle, K, M.m Stulz R.M. (2013). "Access to capital, investment, and the financial crisis". Journal of Financial Economics, 110(2), 280-299. DOI 10.1016/j.fineco.2013.02 .014

[4] Athanasoglou, P.P., Delis, M.D, Staikouras, C.K. (2006). "Determinants of bank profitability in the south eastern region". Journal of Financial Decision Making, 2, 1-17. ResearchGate, net/publication/264861379

[5] Ernest \& Young (2010). The Ernest \& Young Risk Report 2010: The Top 10 Risks for Business. $1^{\text {st }}$ ed 2010. EYGM Limited. pp 3-8

[6] Deloitte (2013). Exploring Strategic Risk. $1^{\text {st }}$ ed. 2013 Deloitte Touche Tohmatsu Limited. pp 5-9

[7] World Economic Forum (2017). Informe de Riesgos Mundiales 2017.12 ${ }^{\text {th }}$ ed. Geneva 2017 pp-1 -20
[8] Allianz Global Corporate (2019). Allianz Risk Barometer: Top Business Risks 2019. Allianz Global Corporate (2019). $1^{\text {st }}$ ed. Munich pp 8-10

[9] Protiviti (2019). Executive Perspectives Money and Foreign Exchange Markets. John Wiley \& Sons, England. $1^{\text {st }}$ ed 2019. North Carolina pp 1-30

[10] Tapiero, Charles S. (2013). Engineering Risk and Finance. Springer US, Boston $20131^{\text {st }}$ ed. DOI:10.1007/978-1-4614 $-6234-7$ pp 33-37

[11] Lai, Tze Leung and Xing, Haipeng (2008). Statistical Models and Methods for Financial Markets. Springer Science, $1^{\text {st }}$ ed. 2008 New York. DOI: 10.1007/978-0387-77827-3 pp- 305-311

[12] Diez de Castro, Luís T. and López Pascual, Joaquín (2001). Dirección Financiera. Planificación, Gestión y Control. Prentice Hall, 2001 Madrid. $1^{\text {st }}$ ed. pp 35-50

[13] Lelyveld, Iman van (2006). Economic Capital Modelling: Concepts, Measurement and Implementation. Risk Books, 2006 London. $1^{\text {st }}$ ed. pp 1-50

[14] Spackova, Olga and Straub, Daniel (2015). "Cost-benefit analysis for optimization of risk protection under budget constraints". Risk Analysis, 35, 941-959. DOI.10.111/risa.1 2310

[15] Nueno, Pedro and Pregel, Gert (1997). "Instrumentos 
financieros al servicio de la empresa". Editorial Deusto, 1997 Bilbao. $1^{\text {st }}$ ed. pp. $70-90$

[16] [16] Rüschendorf, Ludger (2013). Mathematical Risk Analysis: Dependence, Risks Bound, Optimal Allocations and Portfolios. Springer Alemania, 2013 Berlin. $1^{\text {st }}$ ed. pp 141-165

[17] MacKenzie, Cameron A. (2014). "Summarizing risk using risk measures and risk indices". Risk Analysis, 34, 2143-2162. DOI:10.111/risa.12220

[18] Borghesi, Antonio and Gaudenzi, Barbara (2013). Risk Management: How to Assess, Transfer and Communicate Critical Risk. Springer Italia, 2013 Milan. $1^{\text {st }}$ ed. pp 43-52

[19] Ogilo Fredrick, Omwoyo Jeremiah and Zipporah Onsomu (2018), "The relationship between liquidity risk and failure of commercial banks in Kenya". Universal Journal of Accounting and Finance, 6(1), pp 7-13, DOI:

\subsection{9/ujaf.2018.060102}

[20] Durban Oliva, Salvador (1994). Introducción a las Finanzas Empresariales. Universidad de Sevilla, 1994 Sevilla. $4^{\text {th }}$ ed. pp 42-45

[21] Torrents Arevalo, Juan Antonio (2008). "El Valor Añadido como Medida de la Eficacia Empresarial". Doctoral Thesis. Universidad Politécnica de Catalunya Barcelona .1st.ed.htt p/hdl.handle.net/10803/6778 p.p 174-182

[22] Alan T. Wang, Wen-Chung Hsu, Wen-Cheng Ho (2019), "Loan loss provisioning of the U.S. commercial banks after the financial crisis". Universal Journal of Accounting and Finance, 7 (2), pp. 29-42, 2019. DOI: 10.13189/ujaf.2019.0 70201

[23] BACH Project (2015) Data Base Construction Sector. European Committee of Central Balance Sheet Data Offices. October http://www.bach.banque-france.fr/?lang=en 